\title{
Political Status of Rongmei Naga Women
}

\author{
Mary Panmei
}

\begin{abstract}
The roles of women in the social and political affairs are regulated by the traditional customs and norms. Examining the role of women at the ideal plane and their tangible rights and obligations is necessary in order to understand their status within the society. In most cases, women are kept out of the decision-making processes. Men, in favour of the traditions and customs get more prestige and values and thereby considered themselves influential in every domains. Women subsist by the idioms of the traditional customs. Their rights are instable and hence make them peripheral in the political power structure of the society. Today, women have played a significant role in their society however their mobility is still limited to a great extent. The philosophy of women as the weaker being continues to exist within the society.
\end{abstract}

Keywords: Custom, law, political, patriarchy, status

\section{Introduction}

In every society, men and women's roles were resolved by social institutions, norms and ideologies. They both play important roles in society however women are not given equal rights. Traditions and customs that were adhered by the society have an effect on the thinking and attitude of both men and women. It holds true that tribal women enjoy equal status with that of men however, various customary practices keep back women from enjoying equal rights with that of men. Vitso (2003) opined that people were habituated to adhering to their own laws as this laws helped in maintaining social stability in their society. She added that in all social systems both men and women have an important role in the proper functioning of society however laws were more stringent for women than for men.

According to Sachidananda (1978), women's roles and status are generally determined by social situations and norms, religious ideologies, eco-systems and by class position. Chatterji (1993) discusses that the traditional notion of women confined to household activities deprived them of equal opportunities for personal growth and social development. Juneja (1994) says that the power of women to make decision mainly emerge from the resources, which the individual can provide to meet the needs and demands of his or her partner. Furer-Haimendorf (1939) states that tribal women status was founded on the role they played in decision-making in the family while men represented the family in their society. Thus, they were not equal to men.

Schapera (1956) discusses that political organisation affects various structures existing in the life of the people, be that of family, clan or tribe as a whole. Tribal societies are not completely detached from each other though they may appear independent. Lucy Mair (1962) mentions that among tribal societies, chiefs are found to be the main power behind the effective working of the political system where they execute their authorities over the people.

Gender issues in patriarchal governance and status of women in private field have to be elucidated. Women "s role has to be taken into account in order to understand their status and autonomy in the public domain. Patriarchal system generally oppressed women's freedom and autonomy. Griffith (1997) mentions that customary law today is about gendered world in which individuals live. She discovers the ways in which gender affects women 's access to law, how women exploit rules, and how they shop for a sympathetic field. Fernandes and Geeta (1987) opined that gender specificity of the tribe on the value of customary practices has not been considered which reflects invariably the dominant male ideology.

Simon (1968) who undertook his studies on customary law, mentioned as to how social, economic and political policies regulated the status of women in South Africa. He pointed out that when colonial authorities were highly conscious of their ,civilising mission", they sought to express bridewealth and polygamy, which degraded the position of women. Later, when policies of segregation and apartheid came into force, the courts and government revived African culture and the tradition of patriarchy was strengthened.

\section{The Rongmei Community}

The Rongmei are one of the major indigenous Naga tribes found in certain areas of North Eastern states of India like Manipur, Assam and Nagaland. Originally, Rongmei are highlanders living in a compact area. Unfortunately, when the British control their entire homeland in the late $18^{\text {th }}$ century, they were compelled to migrate to Manipur, Assam and Nagaland. The larger portion of this tribe concentrates in the state of Manipur, particularly in Tamenglong district which is the western flank of Manipur (Nabachandra, 1995:409-410).

According to myth and legend, the Rongmei is believed to have originated from Taobhei a cave at Makhel located in Northern part of Manipur. Some narrated to have originated from South- western Chinese region who speak SinoTibetan language where they migrated to northern South East Asia and later North East India via Myanmar and South East Asia after 2000 BC. Like the other Nagas, the Rongmei have Mongoloid features. The society is patriarchal and patrineal (AZSU, 2009).

\section{Village Administration}

The Rongmei village administration centred around the Pie, that is a village council. The village council is run by the Nampou and the clan representatives. The Nampou is the village chief and his office is hereditary. Other members of the village council are selected from different clans in the 


\section{International Journal of Science and Research (IJSR) \\ ISSN (Online): 2319-7064 \\ Index Copernicus Value (2013): 6.14 | Impact Factor (2014): 5.611}

village. Only male members are allowed to be part of the village council whereas women are restricted from this domain. Various organisations that exist within the village are control by the village council, though each one of them functions autonomously. Till today, traditional customs play a vital role in regulating the life of the people despite of having several changes in the norms or laws of the community.

Today, in some villages, the village council is headed by the village chairman. He is officially chosen by the consensus of the villagers. The village council promotes community consciousness where people had respect for age and tradition. Thus, traditional council survived not only representing able-bodied men of the community, but also consists of average people and it decides, neither by an act of its leaders nor by a majority vote, but by consensus.

Under the Manipur Village Authority Act 1956, its jurisdiction has been circumscribed which recognises village councils as its local bodies. Here, only male members were given authority to exercise in village administration. The traditional village bodies continue to exist and the District Autonomous Council (DAC) recognise the village chief 's role in administering justice (Das, 1985). Thus, the chief or the chairman and its council are given statutory position. However, all of them deny political rights to women and deprive them of participation in their village structures.

\section{Perception Towards Women}

The imposition of patriarchal system since the beginning further fused in keeping the women in the margin of the community. Women's right are instable and hence makes them peripheral in the political power structure of the society. Men on the basis of tradition usually have more power and influence in the society. Having a peripheral social existence, therefore contradict women the right to participate in political domain.

Women have no direct access to the public spheres. They rely mostly on men to mediate on their socio-legal and economic problems. Since men's roles are more scrupulously utilised in the public domain, all tasks related to household domain are consigned to women. Occupations pursued by men are where prestige is attached. Consequently, acquirement of power and prestige appears as a natural incident in the life of man. Men considered themselves suitable in political domain as they represent the people for any predicaments that arise within their community.

Rongmei women have played a significant role in their society in almost every aspect of life however their roles were undermined by traditions and customs. Thus, women had to subsist by the idioms and situations of the traditional customs. Women are considered as the weaker section and their status are lower as compared to men. They are not encouraged to participate in politics or administrative related activities because those were regarded to be the realm of men. The mobility of women is limited to a great extent.
The social roles of women are valued as economic asset in the domestic sphere but their voices are muted in their social, political and economic domains. Though not expressed openly, the tradition of this community is based on the assumption of their intellectual inferiority. They considered that men alone have the mental abilities required for administration.

In favour of the tradition, men felt that women are overloaded with domestic work and so to give time in outside household affairs will be a heavy task and her lesser involvement in household arena would disintegrate her family relationship. On the other hand, women think that there are many women who understand the problems of their society better than men do and that, they should be allowed participation in politics. Today, Rongmei community considered that if women are intelligent and capable they should be allowed to contest elections and even hold political position.

Since, women do not participate in politics, the powerbearers want them to remain as they are. They believe they are liable to external pressures whereby it is recognised that unfamiliar contact may render ambiguous inadequacy on some of the customary regulation for relating human relations and satisfying emergent wants or they may call into question the validity of the tribe's universal values. This led the members of the society, men in particular, to establish and preserve a cultural identity in the face of challenges from other community.

\section{Political Status}

Even today, Rongmei women have no political control in their society. In the existing village administration, no single post is reserved for women. They are excluded from village level arbitration machinery, henceforth, women do not attend meetings in the village council. When a woman is related to the dispute parties or is required as a witness only than she is convened to the council. If a woman seeks the intervention of the arbitrary machinery, she will in all possibility, be the only woman present amongst several men. Women have less say in any political matters but they do enjoy certain rights with issues concerning to women. Most of the issues relating to women were assigned to the women organisation where they make decision.

There is lack of political power and participation of women in external matters due to the traditional landholding system which created the growth of patrilineal forms of inheritance. Earlier, the British land settlement operations in tribal areas gave way to outsiders with greater resources, which led to rising land alienation. Ultimately, the scarcity of land changed the power balance between men and women. It permitted men to control the land, and subdue women, who provide almost all the labour. The external political structure, owing their support to hierarchical government machinery with gender bias, fostered less egalitarian and a very suppressive social structure. Women, thus, could not come forward with their rights because of excessive male domination and an increasing conflict between their traditional misrepresentation and their modern imperative representation. Changes are there in favour of women

\section{Volume 4 Issue 12, December 2015}




\section{International Journal of Science and Research (IJSR) \\ ISSN (Online): 2319-7064}

Index Copernicus Value (2013): 6.14 | Impact Factor (2014): 5.611

however they are not given full rights as men are not ready to share power with women. Men believed that it would be against their traditional laws and norms.

For cultural maintenance, women have been made to remain ignorant about the political way of life and thus, unaware of their right of representation. They over-work to make ends meet and have no time to think of their participation in the political sphere. As a result, no women among the Rongmei are seen to have contested in the elections although they enrolled as voters and do caste votes. Such attitude of women can only be taken away if we give due representation to the educated women who are present within the community.

In religious domain, Christianity in particular, women have lesser control. They cannot head the Church. Even if women hold leadership position within the Church, yet they remain inferior where administration of the Church is concerned. All the Churches are headed by males known as ,Pastorsee. Thus, we see that patriarchy subsist even in Christian that effects the involvement of women in religious domain. Nevertheless, by the coming of Christianity, there are changes among the Rongmei society. Today, the Christian standard of promoting love and equality has consigned women in comparable with men to great extent.

Women managed to gain if legal provisions are enacted in their favour but law is inadequate. Reservations are not a remedy for equality but are only a step in undoing the historical injustice meted out to them. The forces of modernisation such as education, politics and constitutional provisions have the capacity to transform societies in favour of gender equity. Women, with their access to education and exposure to social activities have begun questioning about their rights that has been regulated by the traditions and customs.

Today, we can see several organisations and institutions where women are the major lead. The Naga Mother Association (NMA), which is a women body have been effectively operating in the states of Assam, Manipur and Nagaland for decades. This association is formed by women of various Naga communities in order to bring positive transformation to the society. The Zeliangrong Woman Union (ZWU), a tribal women organisation in Manipur is successively working to bring constructive change within the community. Despite the services, women have rendered so far, their voices remain restrained in political domain.

Women, on the other hand underestimate their ability and thus, makes themselves irrelevant in accepting their rights. There is no law that completely forbids women from fitting the leadership but women themselves limited the confidence to obtain such position. They considered that they are not accustomed to experiment into politics, and so it is effortless to visualize them becoming leaders and members in political domain. Even if they get the chance to be the leaders, they think they would not be able to execute the task efficiently.

However, women begun to realized that they are as capable as men of taking an active part in the political domain. They have made big strides in higher education and hold certain administrative posts within their society. In many ways, women have contributed to bring positive alteration to their society. Thus, women could not be forever denied from leadership roles.

Rongmei society, today, felt that if women have leadership qualities they should be allowed to become leaders. Women have started exploring beyond their society and become capable and have proved that they can outgrow their domestic chores. Indeed, Rongmei women have good status and privileges in their community yet they are still kept out of traditional realm of their society.

\section{Conclusion}

It is seen that women had no equal rights with men in the political domain although they played important role in the society. Women are known to influence leadership position in order to bring positive transformation in the society. However, regardless of all their contributions and involvement, women have inferior status. Educations have brought about change in the life of women. But women are not given direct rights to participate in the society as well as in state political system. Women on the other hand, felt that they are not capable of shouldering any responsibilities. Till today, traditional customs and values are retained that further restricts women in any political settings within the society.

\section{References}

[1] AZSU 2009 A Brief Account of Zeliangrong Nagas. Guwahati: Saraighat Offset Press.

[2] Chaterji, S.A. 1993 The Tribal Women. Delhi: Omson Publication.

[3] Das, Rajat Kanti 1985 Manipur Tribal Scene Studies in Society and Change. New Delhi: Inter-India Publications.

[4] Fernandes, Walter and Geeta Menon 1987 Tribal Women and Forests Economy: Deforestation, Exploitation and Status Change. New Delhi: Indian Social Institute.

[5] Griffiths, Anne, M. O. 1997 In the Shadow of Marriage: Gender and Justice, in African Community. Chicago: University of Chicago Press.

[6] Furer-Haimendorf, C.V. 1939 The Naked Nagas. Delhi: Spectrum Publications.

[7] Juneja, K. 1994 "Women, Power and Position in Rural and Urban Patriarchal Households: A Comparative study". Man in India. 74 (1).

[8] Kahmei, N. 1995 "The Zeliangrong Nagas". In Nabachandra, Manipur: Past and Present. Volume 3, 411417.

[9] Mair, L.1962 Primitive Government. USA: Penguin Books Ltd.

[10] Sachinanda 1978 "Social Structure, Status and Mobility Pattern: The Case of Tribal Women". Man in India 58 (1).

[11] Schapera, I. 1956 Government and Politics in Tribal Government Southampton: The Millbrook Press.

[12] Simon, H. J. 1968 African Women: Their Legal Status in South Africa Illinois: North Western University Press.

[13] Vitso, Adino 2003 Customary Law and Women: The Chakhesang Nagas. New Delhi: Daya Publishing House.

\section{Volume 4 Issue 12, December 2015}

